\title{
PENGARUH SUHU PIROLISIS DAN JUMLAH KATALIS KARBON AKTIF TERHADAP YIELD DAN KUALITAS BAHAN BAKAR CAIR DARI LIMBAH PLASTIK JENIS POLIPROPILENA
}

\author{
Rio Nazif*, Erlangga Wicaksana, Halimatuddahliana \\ Departemen Teknik Kimia, Fakultas Teknik, Universitas Sumatera Utara, \\ Jl. Almamater Kampus USU, Medan 20155, Indonesia \\ *Email : nazifrio@yahoo.com
}

\begin{abstract}
Abstrak
Penggunaan energi di Indonesia secara umum meningkat pesat sejalan dengan pertumbuhan penduduk, pertumbuhan perekonomian maupun perkembangan teknologi. Kebutuhan plastik nasional saat ini cukup besar dan meningkat sejalan dengan pertumbuhan penduduk. Konsumsi plastik per kapita di Indonesia, sekitar $10 \mathrm{~kg} / \mathrm{kapita} /$ tahun. Salah satu cara untuk memanfaatkan limbah plastik tersebut adalah dengan memanfaatkannya menjadi bahan bakar cair dengan proses pirolisis. Hal ini dapat dilakukan karena plastik merupakan bahan yang tersusun atas monomer-monomer yang membentuk polimer. Tujuan dari penelitian ini adalah untuk mengamati pengaruh variabel proses (suhu proses dan jumlah katalis karbon aktif) terhadap yield dan kualitas bahan bakar cair yang dihasilkan dari plastik bekas kemasan gelas (PBKG) jenis polipropilena meliputi densitas/ specific gravity/ API gravity, viskositas kinematis, heating value, karakteristik Fourier Transform Infra - Red (FTIR), dan karakteristik Gas Chromatography - Mass Spektrofotometer $(G C-M S)$. Proses pirolisis dilakukan menggunakan reaktor semi batch stainless steel unstirred. Sampel yang digunakan sebanyak 500 gram plastik bekas kemasan gelas (PBKG) jenis polipropilena (PP). Kemudian ditambahkan katalis, dengan rasio Karbon aktif : Polipropilena (b : b) yaitu $1: 10 ; 1,5: 10 ; 2: 10 ; 2,5: 10$; dan $3: 10$. Variabel suhu yang digunakan adalah $200{ }^{\circ} \mathrm{C}, 250{ }^{\circ} \mathrm{C}$, $300{ }^{\circ} \mathrm{C}$ dan $350{ }^{\circ} \mathrm{C}$ dan dipertahankan selama 2 jam. Langkah terakhir adalah kondensasi, kemudian produk liquid dianalisis densitas, viskositas, specific gravity, API gravity, analisisis FTIR dan analisis chromatography-mass spectrometry (GC-MS). Dari analisis GC-MS, produk liquid hasil pirolisis banyak mengandung hidrokarbon fraksi diesel yaitu $\mathrm{C}_{8}$ sampai $\mathrm{C}_{21}$. Suhu pirolisis dimana menghasilkan senyawa hidrokarbon mendekati mutu diesel yang terbaik adalah pada $300{ }^{\circ} \mathrm{C}$ dengan rasio Karbon Aktif : PP yaitu 10: 2, serta analisis terhadap produk bahan bakar cair yang dihasilkan, menyatakan bahan bakar cair mendekati mutu diesel, dimana memenuhi standar dari diesel komersial
\end{abstract}

Kata Kunci : pirolisis, karbon aktif, polipropilena, bahan bakar cair

\begin{abstract}
The energy usage in Indonesia generally increase by the population growth, the economic growth and technology. Today, national demands of plastic is quite large and it continues to grow by the population growth. Plastics consumption in Indonesia is about $10 \mathrm{~kg}$ per capita annualy. One of the methode to reuse the plastic waste is making it to the liquid fuel by pyrolisis process. It is possible to do because the plastic is consist of monomers which will form the polymer. The purpose of this study is to observe the effect of process variable (process temperature and active carbon catalyst) for yield and the quality of liquid fuel from polypropylene packaging glass plastic waste. Quality parameters that have been analyzed consist of density, specific gravity / API gravity, kinematic viscosity, heating value, Fourier Transform Infra-Red (FTIR) characteristic, Gas Chromatography - Mass Spektrofotometer (GC-MS) characteristic, the pyrolisis process was using semi batch stainless steel unstirred reactor. Pyrolysis process was used 500 gram of polypropylene (PP) packaging glass plastic waste. Then carbon active catalyst is added by ratio catalyst : propilene $(\mathrm{w} / \mathrm{w})$ were $1: 10 ; 1,5: 10 ; 2: 10 ; 2,5: 10 ;$ dan $3: 10$. Temperature variables were $200{ }^{\circ} \mathrm{C}, 250{ }^{\circ} \mathrm{C}, 300{ }^{\circ} \mathrm{C}$ dan $350{ }^{\circ} \mathrm{C}$ and it's maintained in 2 hours. The last step was condensation, then the quality parameter of liquid product was analysed. From GC-MS analysis, the liquid product of pyrolisis most contains diesel fraction hydrocarbon that is $\mathrm{C}_{8}$ till $\mathrm{C}_{21}$. The pyrolisis temperature which produce the hydrocarbon near the best quality diesel is at $300{ }^{\circ} \mathrm{C}$ with ratio active carbon : PP is 10:2, and the analysis to the liquid fuel product claims that the liquid fuel is near to the best quality diesel, which fullfills the standard from commercial diesel.
\end{abstract}

Keywords : pirolysis, active carbon, polypropylene, liquid fuel

\section{Pendahuluan}

Penggunaan energi di Indonesia secara umum meningkat pesat sejalan dengan pertumbuhan penduduk, pertumbuhan perekonomian maupun perkembangan teknologi [1]. Beberapa upaya yang telah dilakukan oleh pemerintah untuk mengatasi krisis energi diantaranya adalah dengan mengembangkan bahan bakar alternatif, yang berasal dari sumber daya energi terbarukan, batubara, hidrogen, nuklir dan lain-lain. Namun, 
penelitian dan pengembangan energi baru yang selama ini dilakukan hanya berfokus pada pengembangan sumber dari bahan nabati, tambang dan nuklir. Padahal masih terdapat banyak sumber lain, salah satunya adalah yang berasal dari limbah atau sampah plastik [13].

Salah satu cara untuk memanfaatkan limbah plastik tersebut adalah dengan memanfaatkannya menjadi bahan bakar cair melalui pirolisis. Hal ini dapat dilakukan karena plastik merupakan bahan yang tersusun atas monomer-monomer yang membentuk polimer. [7]. Berdasarkan penelitian terdahulu karbon aktif adalah katalis yang efisien untuk jenis degradasi dan dapat menghasilkan jumlah yang lebih tinggi dari senyawa aromatik. Karbon aktif dipilih karena menunjukkan sifat mekanik yang tinggi, tahan panas, murah dan sebagai katalis terbaik untuk degradasi katalitik limbah PE dimana suhu optimum untuk reaksi katalitik adalah $450{ }^{\circ} \mathrm{C}$ [21].

\section{Teori}

Plastik adalah polimer non-biodegradable sebagian besar mengandung karbon, hidrogen, dan beberapa unsur lainnya seperti klorin, nitrogen dan lain lain. Karena sifat nonbiodegradable, sampah plastik memberikan kontribusi yang signifikan terhadap masalah pengelolaan sampah kota. Produksi plastik secara signifikan tumbuh, saat ini produksi plastik lebih dari 200 MT di seluruh dunia setiap tahunnya [13]. Polipropilena termasuk kelompok plastik termoplastik, dibentuk dari monomer tunggal melalui polimerisasi [5]. Gambar struktur polipropilena disajikan pada Gambar 1 .

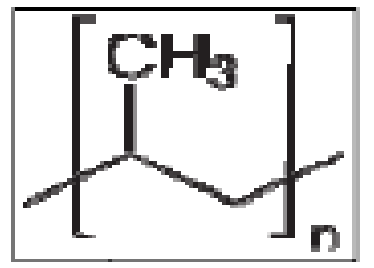

\section{Gambar 1. Rumus Struktur Polipropilena [5]}

Karbon aktif merupakan padatan berpori yang mengandung 85\% - 95\% karbon. Bahan-bahan yang mengandung unsur karbon dapat menghasilkan karbon aktif dengan cara memanaskannya pada suhu tinggi [18]. Karbon aktif adalah katalis yang efisien untuk jenis degradasi dan dapat menghasilkan jumlah senyawa aromatik yang lebih tinggi.

Pirolisis yaitu pemanasan dalam kondisi bebas oksigen, mengurai senyawa organik dari suatu bahan menjadi produk cair dan gas dengan melepaskan ikatan bahan-bahan anorganik yang terikat [9]. Proses pirolisis dapat disebut juga dengan proses perengkahan atau cracking.
Cracking adalah proses pemecahan rantai polimer menjadi senyawa dengan berat molekul yang lebih rendah. Hasil dari proses cracking plastik ini dapat digunakan sebagai bahan kimia atau bahan bakar.

Ada dua macam proses cracking yaitu thermal cracking dan catalytic cracking [13]. Thermolisis (Yunani: pur = api, termos = hangat; luo = melonggarkan), adalah proses dekomposisi kimia dan termal, umumnya mengarah ke molekul yang lebih kecil atau proses cracking tanpa menggunakan katalis [20]. Catalytic Cracking merupakan proses cracking yang menggunakan katalis untuk melakukan reaksi perengkahan, dimana dengan adanya katalis dapat mengurangi temperatur dan waktu reaksi [20].

Mekanisme reaksi catalytic cracking dari rantai polimer sama dengan jalur dari catalytic cracking hidrokarbon di pabrik penyulingan minyak bumi, mekanisme ini telah dipelajari selama beberapa tahun [19]. Mekanisme catalytic cracking hidrokarbon berupa reaksi ion, seperti pada katalis jenis zeolit memiliki pusat bronsted asam kuat, yang akan mentransfer ion hidrogen ke rantai polimer [8], ion yang dihasilkan dapat distabilkan oleh $\beta$ - splitting, isomerisasi atau mentransfer reaksi hidrogen. Skema selanjutnya menunjukkan reaksi berbeda yang dapat terjadi, masing-masing terjadi bergantung pada suhu dan luas permukaan katalis yang digunakan [12].

\section{Metodologi Penelitian}

Bahan-bahan yang digunakan dalam penelitian ini adalah plastik bekas kemasan gelas (PBKG) jenis polipropilena dan karbon aktif powdered. Peralatan yang digunakan dalam penelitian ini adalah reaktor pirolisis, termometer, kondensor, corong gelas, spatula, neraca analitik, beaker glass, erlenmeyer, gelas ukur, viskosimeter Ostwald, fourier transform infra-red, gas chromatography mass spectrophotometer, piknometer, kertas saring Whatman No.1.

\section{Prosesur Penelitian.}

1. Penyediaan Bahan Baku Utama

Bahan baku utama yaitu polipropilena disediakan berdasarkan prosedur berikut:

- Polipropilena diperoleh dari Plastik Bekas Kemasan Gelas (PBKG) dicuci.

- PBKG dipotong dengan ukuran 2 × $2 \mathrm{~cm}$

- Potongan PBKG ini disediakan sebanyak \pm 500 gram.

2. Proses pirolisis

Proses menggunakan reaktor semi batch stainless steel unstirred. Reaktor dipanskan hingga suhu yang diinginkan, kemudian masukkan kedalam reaktor 500 gram PBKG dan katalis (dengan penggunaan katalis), dengan rasio Karbon aktif : Polipropilena (b : b) yaitu $1: 10$; 
$1,5: 10 ; 2: 10 ; 2,5: 10 ;$ dan $3: 10$ dan variabel suhu yang digunakan adalah $200{ }^{\circ} \mathrm{C}, 250{ }^{\circ} \mathrm{C}, 300$ ${ }^{\circ} \mathrm{C}$ dan $350{ }^{\circ} \mathrm{C}$, dipertahankan selama 2 jam. Langkah terakhir adalah kondensasi, kemudian produk liquid di saring menggunakan kertas whatmen no 1.

3. Penentuan Yield Proses Pirolisis

Yield merupakan hasil yang diperoleh dari proses pirolisis, analisis yield berfungsi untuk melihat seberapa besar yield yang dihasilkan dengan pengaruh suhu proses dan perbandingan komposisi dari PBKG dengan katalis yaitu karbon aktif

4. Pengujian Kualitas Bahan Bakar Pirolisis

Uji densitas/ specific Gravity/ API gravity, uji viskositas kinematik, karakterisasi fourier transform infra - red (FTIR), karakterisasi gas chromatography mass spectroscopy (GCMS) dan Analisis Heating Value.

\section{Hasil}

1. Analisis Bahan Baku Plastik Bekas Kemasan Gelas (PBKG) Jenis Polipropilena (PP)

Pada penelitian ini digunakan Plastik Bekas Kemasan Gelas (PBKG) jenis Polipropilena (PP) sebagai bahan baku. Karakterisasi FTIR (Fourier Transform Infra - Red) plastik bekas kemasan gelas (PBKG) jenis polipropilena dilakukan untuk mengidentifikasi gugus fungsi dari PBKG. Gambar Karakterisasi FTIR dari PBKG jenis polipropilena disajikan pada Gambar 2.

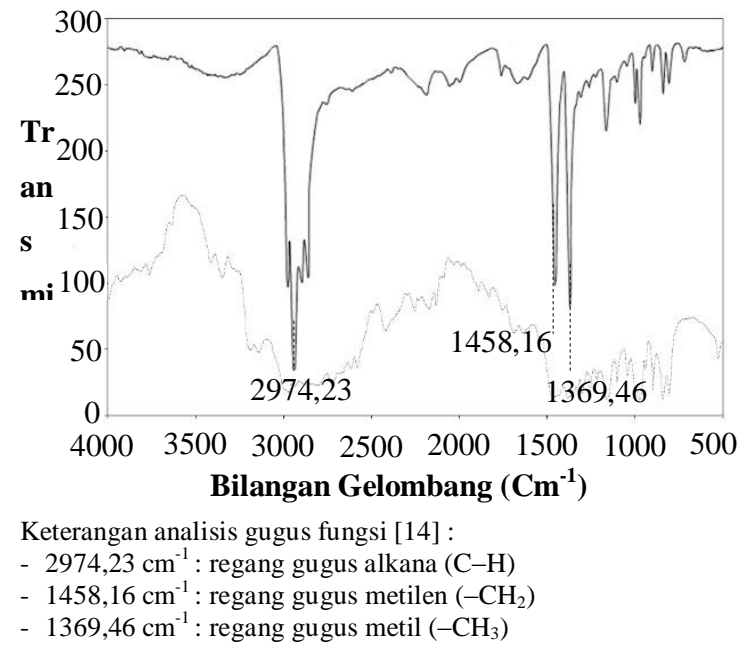

$\begin{array}{llrr}\text { Gambar 2. Karakterisasi } & \text { FTIR Plastik } & \text { Bekas } \\ \text { Kemasan } & \begin{array}{l}\text { Gelas Jenis } \\ \text { Polipropilena Murni }\end{array} & & \text { dan } \\ \text { Polipropilena } & \end{array}$

Hasil spektrum FTIR jelas menunjukkan terbentuknya gugus - gugus yang mendukung PBKG jenis PP yang memiliki struktur seperti Gambar 2. Selain itu, hasil spektrum FTIR PBKG jenis PP juga memiliki kesamaan dengan hasil spektrum FTIR PP murni dan puncak serapan gugus alkana dan metilen pada FTIR PBKG tidak setajam puncak serapan pada PP murni. Hal ini disebabkan karena PBKG merupakan jenis PP yang telah diproses dengan melibatkan penggunaan senyawa aditif, seperti antistatik, antioksidan, dan lain sebagainya. Kehadiran senyawa aditif ini juga menyebabkan perubahan puncak serapan yang terbentuk

\section{Pengaruh Suhu dan Jumlah Katalis terhadap Perolehan Yield}

Adapun pengaruh suhu dan jumlah katalis karbon aktif terhadap perolehan yield diperlihatkan pada Gambar 3.

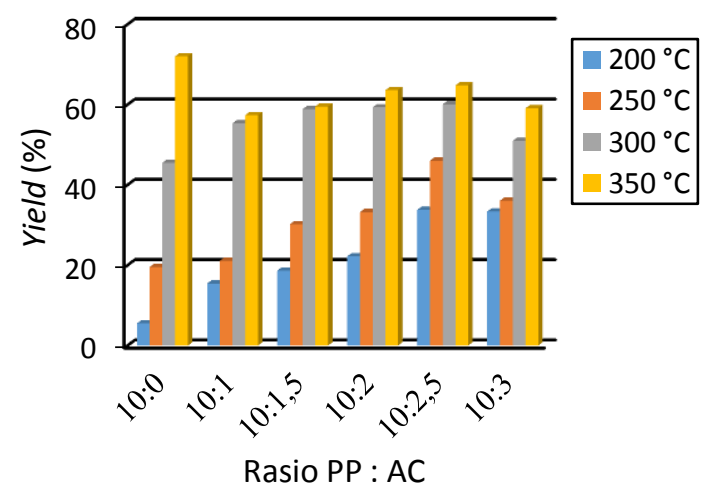

Gambar 3. Pengaruh Suhu dan Jumlah Katalis Karbon Aktif terhadap Perolehan Yield

Berdasarkan grafik dapat dilihat bahwa total persen perolehan yield tanpa menggunakan katalis meningkat seiring dengan peningkatan suhu pirolisis dimana pada suhu $200^{\circ} \mathrm{C}, 250{ }^{\circ} \mathrm{C}, 300{ }^{\circ} \mathrm{C}$ dan $350{ }^{\circ} \mathrm{C}$ yield masing-masing sebesar 5,539, 19,583, 45,548 dan 72,073\%. Peningkatan dari suhu pirolisis membuat konversi juga meningkat dimana lebih banyak memproduksi molekul yang lebih kecil [2].

Berdasarkan grafik hasil penelitian, yield dari pirolisis tanpa menggunakan katalis meningkat seiring dengan peningkatan suhu dan pada suhu akhir yaitu $350{ }^{\circ} \mathrm{C}$ produk cairan belum menunjukkan penurunan konversi, ini disebabkan suhu pirolisis yang digunakan menghasilkan gas yang tidak mudah terkondensasi lebih sedikit dan menghasilkan cairan lebih banyak.

Dari grafik hasil penelitian terlihat pada suhu $350{ }^{\circ} \mathrm{C}$ penggunaan katalis karbon aktif tidak menunjukkan yield lebih besar dari pada pirolisis tanpa menggunakan katalis dimana yield tanpa menggunakan katalis yaitu 72,073 \%. Penggunaan katalis membuat distribusi produk menjadi kurang signifikan pada temperatur tinggi, akan seperti reaksi pirolisis tanpa menggunakan katalis. Penggunaan katalis pada pirolisis PBKG dengan rasio PP : Karbon Aktif ; 10 : 3 mengalami penurunan yield, disebabkan oleh 
jumlah katalis terlalu banyak, membuat tidak terlalu berpengaruh terhadap konversi yang dihasilkan dan katalis karbon aktif termasuk dalam jenis katalis padatan asam konvensional, dimana pengaruh keasaman yang tinggi membuat produk gas lebih banyak dihasilkan. Dalam hal ini pirolisis yang dilakukan dengan menggunakan katalis, rasio PP : Karbon Aktif ; 10 : 2,5 pada suhu $350{ }^{\circ} \mathrm{C}$ menghasilkan yield yang paling tinggi yaitu $64,831 \%$.

\section{Analisis Densitas / Specific Gravity / API Gravity}

Dari hasil percobaan yang telah dilakukan, diperoleh densitas bahan bakar cair hasil pirolisis PBKG seperti yang telah disajikan pada Tabel 1.

Tabel 1. Hasil Analisis Densitas Bahan Bakar Cair

\begin{tabular}{|c|c|c|}
\hline $\begin{array}{c}\text { Suhu } \\
\text { Pirolisis } \\
\left({ }^{\circ} \mathrm{C}\right)\end{array}$ & $\begin{array}{c}\text { Rasio Katalis : } \\
\text { Polipropilena } \\
\text { (b/b) }\end{array}$ & $\begin{array}{c}\text { Densitas } \\
\text { Bahan Bakar } \\
\text { Cair }\left(\mathrm{g} / \mathrm{cm}^{3}\right) \\
\left(15^{\circ} \mathrm{C}\right)\end{array}$ \\
\hline 200 & $0: 10$ & 0,748 \\
\hline 250 & $0: 10$ & 0,747 \\
\hline 300 & $0: 10$ & 0,658 \\
\hline 350 & $0: 10$ & 0,767 \\
\hline 200 & $1: 10$ & 0,735 \\
\hline 250 & $1: 10$ & 0,748 \\
\hline 300 & $1: 10$ & 0,761 \\
\hline 350 & $1: 10$ & 0,776 \\
\hline 200 & $1,5: 10$ & 0,746 \\
\hline 250 & $1,5: 10$ & 0,756 \\
\hline 300 & $1,5: 10$ & 0,771 \\
\hline 350 & $1,5: 10$ & 0,744 \\
\hline 200 & $2: 10$ & 0,767 \\
\hline 250 & $2: 10$ & 0,756 \\
\hline 300 & $2: 10$ & 0,771 \\
\hline 350 & $2: 10$ & 0,776 \\
\hline 200 & $2,5: 10$ & 0,752 \\
\hline 250 & $2,5: 10$ & 0,768 \\
\hline 300 & $2,5: 10$ & 0,771 \\
\hline 350 & $2,5: 10$ & 0,772 \\
\hline 200 & $3: 10$ & 0,770 \\
\hline 250 & $3: 10$ & 0,759 \\
\hline 300 & $3: 10$ & 0,773 \\
\hline 350 & $3: 10$ & 0,778 \\
\hline
\end{tabular}

- Dicampur dengan Solar dan Memenuhi Standar Diesel komersial

Dari Tabel 1 densitas yang diperoleh dari penelitian berkisar antara 0,658-0,778 $\mathrm{g} / \mathrm{ml}$. Mishra et al melakukan pirolisis limbah plastik polipropilena selama 60 menit, menggunakan katalis nikel pada suhu pirolisis $550{ }^{\circ} \mathrm{C}$, densitas yang dihasilkan yaitu $0,7930 \mathrm{~g} / \mathrm{ml}$ [17]. Standar densitas yang diterapkan Pemerintahan Indonesia untuk diesel 48 (Solar) berkisar antara 0,815-
0,870 [15]. Pencampuran bahan bakar hasil pirolisis dengan bahan bakar diesel dapat memberikan kualitas bahan bakar yang lebih baik dimana hasil densitas dapat memenuhi standar [15]. Mukherjee dan Thamotharan melakukan pengujian terhadap campuran bahan bakar plastik dengan diesel pada mesin diesel silinder ganda dan mendapatkan hasil yang terbaik pada perbandingan $20 \%$ bahan bakar plastik dan $80 \%$ diesel [11]. Pencampuran antara bahan bakar cair hasil pirolisis dengan solar, menggunakan sampel PP : Karbon Aktif yaitu $10: 2$ pada suhu $300{ }^{\circ} \mathrm{C}$ dengan perbandingan $20 \%: 80 \%$, diperoleh densitas $0,848 \mathrm{~g} / \mathrm{ml}$ dimana memenuhi standar diesel 48 (Solar). Dapat disimpulkan dengan mencampurkan bahan bakar cair yang dihasilkan dengan diesel dapat meningkatkan kualitas bahan bakar.

Dari hasil percobaan yang telah dilakukan juga diperoleh specific gravity dan API gravity hasil pirolisis $P B K G$ seperti yang telah disajikan pada Tabel 2 .

Tabel 2. Hasil Analisis Specific Gravity dan API Gravity Bahan Bakar Cair

\begin{tabular}{|c|c|c|c|}
\hline $\begin{array}{c}\text { Suhu } \\
\text { Pirolisis } \\
\left({ }^{\circ} \mathrm{C}\right)\end{array}$ & $\begin{array}{c}\text { Rasio katalis } \\
\text { : } \\
\text { Polipropilena } \\
\text { (b/b) }\end{array}$ & $\begin{array}{c}\text { Spesific } \\
\text { Gravity }\end{array}$ & $\begin{array}{c}\text { API } \\
\text { Gravity }\end{array}$ \\
\hline 200 & $0: 10$ & 0,749 & 57,358 \\
\hline 250 & $0: 10$ & 0,748 & 57,615 \\
\hline 300 & $0: 10$ & 0,659 & 83,257 \\
\hline 350 & $0: 10$ & 0,768 & 52,862 \\
\hline 200 & $1: 10$ & 0,736 & 60,745 \\
\hline 250 & $1: 10$ & 0,749 & 57,358 \\
\hline 300 & $1: 10$ & 0,761 & 54,337 \\
\hline 350 & $1: 10$ & 0,777 & 50,693 \\
\hline 200 & $1,5: 10$ & 0,747 & 57,872 \\
\hline 250 & $1,5: 10$ & 0,756 & 55,584 \\
\hline 300 & $1,5: 10$ & 0,772 & 50,455 \\
\hline 350 & $1,5: 10$ & 0,745 & 58,388 \\
\hline 200 & $2: 10$ & 0,768 & 52,862 \\
\hline 250 & $2: 10$ & 0,756 & 55,584 \\
\hline 300 & $2: 10$ & 0,772 & 51,891 \\
\hline 350 & $2: 10$ & 0,777 & 50,693 \\
\hline 200 & $2,5: 10$ & 0,752 & 56,594 \\
\hline 250 & $2,5: 10$ & 0,769 & 52,618 \\
\hline 300 & $2,5: 10$ & 0,772 & 51,891 \\
\hline 350 & $2,5: 10$ & 0,773 & 51,650 \\
\hline 200 & $3: 10$ & 0,771 & 52,133 \\
\hline 250 & $3: 10$ & 0,759 & 54,834 \\
\hline 300 & $3: 10$ & 0,774 & 51,410 \\
\hline 350 & $3: 10$ & 0,779 & 50,218 \\
\hline
\end{tabular}

Dicampur dengan Solar dan Memenuhi Standar Diesel komersial 
Dari Tabel 2 bahan bakar cair yang dihasilkan memiliki nilai API gravity berkisar antara 50 61. Pencampuran antara solar dengan bahan bakar cair hasil pirolisis menggunakan sampel PP : Karbon Aktif yaitu 10:2 pada suhu $300{ }^{\circ} \mathrm{C}$, dengan perbandingan $20 \%: 80 \%$, diperoleh nilai API gravity sebesar 35,115 yang telah memenuhi standar API gravity dari solar pada $60{ }^{\circ} \mathrm{F}(15,6$ $\left.{ }^{\circ} \mathrm{C}\right)$ yaitu 30 sampai 42 [4], sedangkan nilai Specific gravity yang diperoleh dari hasil pencampuran sebesar 0,849 juga telah memenuhi standar Specific gravity dari solar yaitu 0,85 [14].

\section{Analisis Viskositas}

Viskositas kinematik adalah tahanan zat cair untuk mengalir karena gaya berat dengan satuan centistokes. Berdasarkan penelitian yang telah dilakukan, viskositas yang dihasilkan adalah seperti yang telah disajikan pada Tabel 3.

Tabel 3. Hasil Analisis Viskositas Kinematik Bahan Bakar Cair

\begin{tabular}{|c|c|c|c|}
\hline $\begin{array}{c}\text { Suhu } \\
\text { Pirolisis } \\
\left({ }^{\circ} \mathrm{C}\right)\end{array}$ & $\begin{array}{c}\text { Rasio } \\
\text { katalis : } \\
\text { Polipropilen } \\
\text { a }(\mathbf{b} / \mathbf{b})\end{array}$ & $\begin{array}{c}\text { Suhu } \\
\left({ }^{\circ} \mathrm{C}\right)\end{array}$ & $\begin{array}{l}\text { Viskositas } \\
\text { Kinematik } \\
\text { (cSt) }\end{array}$ \\
\hline 200 & $0: 10$ & 40 & 0,829 \\
\hline 250 & $0: 10$ & 40 & 1,457 \\
\hline 300 & $0: 10$ & 40 & 1,362 \\
\hline 350 & $0: 10$ & 40 & 1,611 \\
\hline 200 & $1: 10$ & 40 & 1,159 \\
\hline 250 & $1: 10$ & 40 & 1,409 \\
\hline 300 & $1: 10$ & 40 & 1,558 \\
\hline 350 & $1: 10$ & 40 & 1,772 \\
\hline 200 & $1,5: 10$ & 40 & 1,172 \\
\hline 250 & $1,5: 10$ & 40 & 1,296 \\
\hline 300 & $1,5: 10$ & 40 & 2,025 \\
\hline 350 & $1,5: 10$ & 40 & 2,497 \\
\hline 200 & $2: 10$ & 40 & 1,635 \\
\hline 250 & $2: 10$ & 40 & 1,498 \\
\hline 300 & $2: 10$ & 40 & 2,248 \\
\hline 350 & $2: 10$ & 40 & 2,004 \\
\hline 200 & $2,5: 10$ & 40 & 1,570 \\
\hline 250 & $2,5: 10$ & 40 & 1,701 \\
\hline 300 & $2,5: 10$ & 40 & 1,617 \\
\hline 350 & $2,5: 10$ & 40 & 1,820 \\
\hline 200 & $3: 10$ & 40 & 1,695 \\
\hline 250 & $3: 10$ & 40 & 1,783 \\
\hline 300 & $3: 10$ & 40 & 1,683 \\
\hline 350 & $3: 10$ & 40 & 1,730 \\
\hline
\end{tabular}

Memenuhi Standar Diesel Komersial

Bahan bakar cair memiliki viskositas berkisar antara 0,829-2,248. Mishra et al melakukan pirolisis limbah plastik polipropilena dengan menggunakan katalis nikel pada suhu $550{ }^{\circ} \mathrm{C}$, viskositas yang diperoleh yaitu $2,149 \mathrm{~mm}^{2} / \mathrm{s}$ [17].
Pemerintah Indonesia menetapkan standar viskositas kinematik diesel komersial yaitu 2,05,0 untuk diesel 48 (Solar) dan 2,0-4,5 untuk Diesel 51 (Pertamina Dex) [15]. Hasil penelitian menunjukkan bahwa nilai viskositas kinematik ada yang memenuhi standar viskositas diesel komersial yaitu pada pirolisis suhu 300 dan 350 ${ }^{\circ} \mathrm{C}$ dengan rasio Karbon Aktif : PP yaitu 1,5 : 10 dan $2: 10$.

\section{Analisis Gas Chromatography Mass Spectroscopy (GCMS)}

Pada percobaan ini produk yang diinginkan adalah produk liquid karena molekul hidrokarbonnya sama dengan fraksi minyak bumi sehingga bisa digunakan sebagai bahan bakar cair terutama fraksi diesel $\left(\mathrm{C}_{8}-\mathrm{C}_{21}\right)$ [3]. Dari proses pirolisis tersebut juga menghasilkan produk gas dan padat sisa plastik yang belum menguap, dalam penelitian ini produk gas dan padat tidak ditentukan.

Berdasarkan hasil analisis GC-MS terjadinya pemutusan rantai polimer dilihat dari presentase area produk menghasilkan fraksi $\mathrm{C}_{8}$ sampai $\mathrm{C}_{21}$ lebih besar, untuk bahan bakar hasil pirolisis tanpa menggunakan katalis yaitu sebesar 87,62\% dan untuk pirolisis dengan menggunakan katalis dengan perbandingan PP : Karbon aktif ; $10: 2$ sebesar 80,81 \%. Hasil analisis GC-MS menunjukkan bahwa fraksi $\mathrm{C}_{8}$ sampai $\mathrm{C}_{21}$ dari pirolisis tanpa katalis pada suhu $350{ }^{\circ} \mathrm{C}$ lebih besar, ini disebakan karena pengaruh suhu pirolisis yang digunakan, tetapi presentase fraksi yang dihasilkan tidak terlalu jauh dengan pirolisis suhu $300{ }^{\circ} \mathrm{C}$ menggunakan katalis karbon aktif, dimana katalis membantu memecah ikatan rantai polimer. Perbandingan distribusi atom $\mathrm{C}$ pada bahan bakar cair yang dihasilkan dari pirolisis menggunakan katalis dan tanpa katalis dapat dilihat pada Gambar 4.

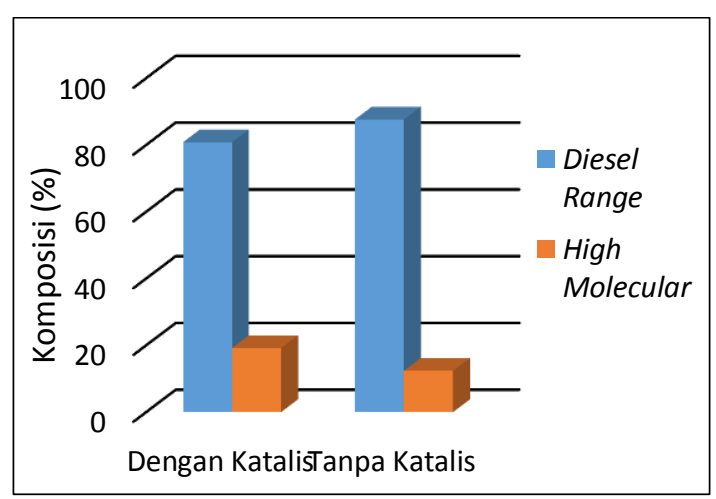

Gambar 4. Pengaruh Penggunaan Katalis terhadap Distribusi Fraksi Bahan Bakar (Diesel Range : $\mathrm{C}_{8}-$ $\mathrm{C}_{21}$; High Molecular Weight : $>\mathrm{C}_{22}$ )

Dapat disimpulkan bahwa dari analisis GCMS bahwa bahan bakar hasil pirolisis dari PBKG 
menghasilkan hidrokarbon fraksi diesel yaitu $\mathrm{C}_{8}$ sampai $\mathrm{C}_{21}$.

\section{Analisis FTIR Produk Bahan Bakar Cair}

Bahan bakar cair yang dihasilkan dianalisis dengan menggunakan FTIR untuk mengetahui gugus fungsi senyawa yang terkandung pada bahan bakar cair yang dihasilkan. Dari hasil pengukuran spektrum FTIR dari produk bahan bakar cair tanpa katalis dengan suhu pirolisis 350 ${ }^{\circ} \mathrm{C}$, terdapat banyak puncak yang teridentifikasi oleh alat.

Berdasarkan hasil analisis FTIR diketahui bahwa komponen terbesar pada produk bahan bakar cair mengandung gugus alkana, alkena, dan sedikit alkohol. Berdasarkan perbandingan antara spektrum hasil FTIR produk bahan bakar cair dengan spektrum hasil FTIR PBKG terlihat bahwa terjadi perubahan yaitu berkurangnya puncak - puncak absorpsi yang kuat pada bahan baku menjadi puncak absorbsi yang lebih sederhana, menunjukkan gugus - gugus senyawa yang terdapat pada bahan baku sudah mengalami pemutusan ikatan dan membentuk ikatan baru yang lebih sederhana. Hasil ini didapatkan dari pemecahan rantai polimer yang tidak teratur dengan menggunakan panas atau disebut proses pirolisis [6].

\section{Analisis Heating Value}

Nilai kalor merupakan jumlah energi kalor yang dilepaskan bahan bakar pada waktu terjadinya oksidasi unsur-unsur kimia yang ada pada bahan bakar tersebut, nilai kalor sangat bergantung berbeda-beda sesuai jenis bahan bakarnya. Analisis diuji terhadap bahan bakar cair hasil pirolisis pada suhu $300{ }^{\circ} \mathrm{C}$ dengan rasio PP : Karbon aktif yaitu 10:2, menggunakan alat kalorimeter bom dan diperoleh heating value yaitu $44903 \mathrm{~kJ} / \mathrm{kg}$ dimana mendekati standar heating value dari diesel yaitu $42000 \mathrm{~kJ} / \mathrm{kg}$ [11], dan dapat disimpulkan bahwa hidrokarbon cair yang diperoleh dari pirolisis plastik bekas kemasan gelas (PBKG) dapat digunakan sebagai bahan bakar.

\section{Kesimpulan}

Peningkatan suhu dan penambahan jumlah katalis terhadap proses pirolisis menghasilkan bahan bakar cair yang terbaik yaitu rasio Katalis PP:Karbon Aktif; 10:2 pada suhu $300{ }^{\circ} \mathrm{C}$ dengan yield sebesar 59,351 \% serta hasil penelitian menunjukkan bahwa bahan bakar cair yang dihasilkan memenuhi standar diesel komersial, diperoleh densitas sebesar $0,848 \mathrm{~g} / \mathrm{ml}$ dan viskositas kinematik sebesar 2,248 cSt, dimana juga menunjukkan keefektifan penggunaan katalis karbon aktif pada pirolisis PBKG jenis polipropilena dan yield tertinggi untuk pirolisis tanpa katalis diperoleh pada suhu $350{ }^{\circ} \mathrm{C}$. Berdasarkan hasil analisis $G C-M S$ komponen bahan bakar hasil pirolisis dari PBKG menghasilkan lebih besar hidrokarbon fraksi diesel yaitu $\mathrm{C}_{8}$ sampai $\mathrm{C}_{21}$.

\section{Daftar Pustaka}

[1] Ane R. Sari, Nur R. Aprianingtyas, Pembuatan Bahan Bakar Cair Dari Tremboso (Sisa Sadapan Lateks) Menggunakan Katalis Zeolit Hy Dan Zsm-5, 2011 : hal. 1 - 8.

[2] Achyut Kumar Panda, Studies on process optimization for production of liquid fuels from waste plastics, Thesis National Institute of Technology, Rourkela, 2011.

[3] Alan Russell, Clare College, MicrowaveAssisted Pyrolysis Of HDPE Using An Activated Carbon Bed. Dissertation Department Of Chemical Engineering And Biotechnology, University Of Cambridge. Inggris, 2012, hal. $39-41$.

[4] Chevron Corporation, Diesel Fuels Technical Review, Chevron Products Company, San Ramon, 2007.

[5] Dan Weckstrom, Changes in mechanical properties of recycled polypropylene, Thesis Plastic Technology, Arcada-University of Applied Sciences. 2012.

[6] Douglas A Skoog, F. James Holler dan Stanley R. Grouch, Principles of instrumental Analysis, Thomson Brooks, 2007.

[7] Febri S. Ningsih., Novesar Jamarun., dan Zulhadjri, Pengaruh Katalis Dalam Pengolahan Limbah Plastik Low Density Polyethylene (LDPE) Dengan Metode Pirolisis, Jurnal Kimia Unand, 2(2) 2013 : hal $128-132$.

[8] Hanna Wilczura-Wachnik, Catalytic cracking of hydrocarbons, Chemical Technology Division, Faculty of Chemistry, University of Warsaw, 2014.

[9] Jawad A. Bhatti, Current State and Potential For Increasing Plastics Recycling in The U.S., Thesis Department Of Earth \& Environmental Engineering $\mathrm{Fu}$ Foundation School Of Engineering \& Applied Science, Columbia University, Columbia, 2010.

[10] J Scheirs, W Kaminsky, Pyrolysis of polymers. 2006. Feedstock Recycling and Pyrolys is of Waste Plastics: Converting Waste Plastics into Diesel and Other Fuels (Australia : John Wiley \& Sons, Ltd. 2006).

[11] Kaustav Mukherjee dan C.Thamotharan, Performance and Emission Test of Several Blends of Waste Plastic Oil with Diesel and Ethanol on Four Stroke Twin Cylinder 
Diesel Engine, Journal of Mechanical and Civil Engineering, 11 (2) 2014 : hal 47-51.

[12] Luis Noreña, Julia Aguilar, Violeta Mugica, Mirella Gutiérrez and Miguel Torres, Materials and Methods for the Chemical Catalytic Cracking of Plastic Waste, Applied Chemistry Research Group, Departamento de Ciencias Básicas, Universidad Autónoma Metropolitana, Azcapotzalco, México, 2012.

[13] Mahendra F. Nugraha., Arifuddin Wahyudi., dan Ignatius Gunardi, Pembuatan Fuel dari Liquid Hasil Pirolisis Plastik Polipropilen Melalui Proses Reforming dengan Katalis $\mathrm{NiO} / \Gamma-\mathrm{Al} 2 \mathrm{O} 3$. Jurnal Teknik Pomits, 2 (2) 2013 : hal. F-299 - F-302.

[14] M. Rezvanipour, F. Alikhani Hesari*, M. Pazouki, Catalytic Pyrolysis of General Purpose PolyStyrene Using Red Mud as a Catalyst, Iranian Journal of Chemical Engineering, 11 (4) 2014 : hal 10-20.

[15] Mochamad Syamsiro, Harwin Saptoadi, Tinton Norsujianto, Putri Noviasria, Shuo Cheng, Zainal Alimuddin, Kunio Yoshikawa, Fuel Oil Production from Municipal Plastic Wastes in Sequential Pyrolysis and Catalytic Reforming Reactors, Energy Procedia, 472014 : hal. 180 - 188.

[16] Nadia K. Dewi, Indonesia`s plastics industry in 2012 Challenges from raw materials and exchange rates Indonesia Update, Juni 2012.

[17] Neeraj Mishra, Sunil Pandey, Bhushan Patil,Mukeshchand Thukur, Ashmi Mewada,Madhuri Sharon, and Maheshwar Sharon, Facile Route to Generate Fuel Oil via Catalytic Pyrolysis of Waste Polypropylene Bags: Towards Waste Management of $>20 \mu \mathrm{m}$ Plastic Bags, Journal of Fuels 2014: hal 1- 10.

[18] Rosita Idrus, Bosi Pahinop Lapanporo, Yoga Satria Putra, Pengaruh Suhu Aktivasi Terhadap Kualitas Karbon Aktif Berbahan Dasar Temperung Kelapa, Journal of Prisma Fisika, 1 (1) 2013 : hal. 50 - 55.

[19] Sachin Kumar, Achyut K. Panda, R.K. Singh, A review on tertiary recycling of highdensity polyethylene to fuel, Journal of Conservation and Recycling, 552011 : hal. $893-910$.

[20] Untoro B. Surono. 2013, Berbagai Metode Konversi Sampah Plastik Menjadi Bahan Bakar Minyak, Jurnal Teknik 3 (1) 2013 : hal. $32-40$.

[21] Yovana S. González, Carlos Costa, M. C Márquez, Pedro Ramos, Thermal and catalytic degradation of polyethylene wastes in the presence of silica gel, 5A molecular sieve and activated carbon, Journal of Hazardous Materials, 2011 : hal 101 - 112. 